\title{
LACTATE: A BIOLOGICAL MARKER OF PHYSICAL ACTIVITY IN COLOMBIAN WEIGHTLIFTING ATHLETES
}

DE HALTEROFILISMO

\author{
LACTATO: UN MARCADOR BIOLÓGICO DE LA ACTIVIDAD FÍSICA EN ATLETAS COLOMBIANOS \\ DE HALTEROFILIA
}

Diana Carolina Zambrano Ríos' (iD (Biomedical Science)

Andrés Jenuer Matta Miramar ${ }^{1}$ (D) (Biomedical Science)

Yecid Mina Paz ${ }^{1}$ (D)

(Physical Activity)

Isabel Cristina Rojas Padilla' (ID

(Nutritionist)

1. Institución Universitaria Escuela Nacional del Deporte, Cali,

Colombia.

\section{Correspondence:}

Diana Carolina Zambrano Ríos.

Calle 9, No 34-01, Cali,

Colombia. 76001.

diana.zambrano@endeporte.edu.co

\begin{abstract}
Introduction: Blood biomarkers are measurable metabolic products that allow objective monitoring of the training process, and their analysis provides an opportunity to improve athletic performance. Objective: To evaluate blood lactate concentrations in a group of the Valle League weightlifting athletes as a tool to determine the effects of training and its direct relationship to performance during competition. Methods: This is an observational cross-sectional study. Lactate levels of 32 weightlifting athletes belonging to the Valle Weightlifting League were evaluated. Blood samples were taken from the ear lobe to quantify the lactate concentration, using a Scout Lactate analyzer. Samples were taken before and after a high intensity training section consisting of four maximum repetition (MR) sports gestures, in which 5 series and 15 repetitions were performed for each sports gesture, with a rest period of 40 seconds between each exercise. The software program SPSS, version 25 , was used to determine the lactate concentrations. Results: An average lactate concentration $22.46 \mathrm{mg} / \mathrm{dL}$ was obtained for the athletes at rest, and an average of $98.30 \mathrm{mg} / \mathrm{dL}$ in the final lactate concentration, after high intensity exercise. Significant differences were found between the initial and final lactate concentrations. Conclusion: Lactate concentration increases with physical activity; it varies from one individual to another; and it can be used as a biomarker of intensity of physical activity in the field of sports. Level of evidence; II type of study: Prognostic Studies Investigating the Effect of a Patient Characteristic on a disease outcome.
\end{abstract}

Keywords: L-lactate dehydrogenase; Basal metabolism; Carbohydrate metabolism; Sports medicine; Muscle strength; Muscle fatigue.

\section{RESUMO}

Introdução: Os biomarcadores sanguíneos são produtos metabólicos mensuráveis que permitem a monitorização objetiva do processo de treino, e sua análise é uma oportunidade para melhorar o desempenho atlético. Objetivos: Avaliar as concentrações de lactato no sangue de um grupo de atletas de halterofilismo da Liga Valle como ferramenta para determinar os efeitos do treino e sua relação direta com o desempenho durante a competição. Métodos: Esteé um estudo transversal e observacional. Foram avaliados os níveis de lactato em 32 atletas da Liga de Halterofilismo Valle. A amostra de sangue foi retirada do lóbulo da orelha com o intuito de quantificar a concentração de lactato com o analisador Scout Lactate. As amostras foram colhidas antes e depois de uma seção de treino de alta intensidade, que consistiu em quatro gestos esportivos de repetição máxima (RM), nos quais foram realizadas 5 séries e 15 repetições para cada gesto esportivo, com um período de repouso de 40 segundos entre cada exercício. O software SPSS, versão 25 foi usado para determinar as concentrações de lactato. Resultados: A concentração média de lactato nos atletas em repouso foi 22,46 mg/dl e a concentração média final foi de 98,30 mg/dl depois de exercício de alta intensidade. Foram encontradas diferenças significativas ao comparar a concentração inicial com a concentração final de lactato. Conclusões: A concentração de lactato aumenta com a realização da atividade física, évariável de um indivíduo para outro e pode ser usada como biomarcador de intensidade da atividade física na área dos esportes. Nível de Evidência II; Estudos prognósticos - Investigação do efeito de característica de um paciente sobre o desfecho da doença.

Descritores: L-lactato desidrogenase; Metabolismo basal; Metabolismo dos carboidratos; Medicina esportiva; Força muscular; Fadiga muscular.

\section{RESUMEN}

Introducción: Los biomarcadores sanguíneos son productos metabólicos mensurables que permiten la monitorización objetiva del proceso de entrenamiento, y su análisis es una oportunidad para mejorar el desempeño atlético. Objetivos: Evaluar las concentraciones de lactato en la sangre de un grupo de atletas de halterofilia de la Liga Valle como herramienta para determinar los efectos del entrenamiento y su relación directa con el desempeño durante la competición. Métodos: Este es un estudio transversal y observacional. Fueron evaluados los niveles de lactato en 32 atletas de la Liga de Halterofilia Valle. La muestra de sangre fue retirada del lóbulo de la oreja con el objetivo de cuantificar la concentración de lactato con 
el analizador Scout Lactate. Las muestras fueron tomadas antes y después de una sección de entrenamiento de alta intensidad, que consistió en cuatro gestos deportivos de repetición máxima (RM), en los que se realizaron 5 series y 15 repeticiones para cada gesto deportivo, con un período de descanso de 40 segundos entre cada ejercicio. El software SPSS versión 25 fue usado para determinar las concentraciones de lactato. Resultados: La concentración promedio de lactato en los atletas en reposo fue $22,46 \mathrm{mg} / \mathrm{dl}$ y la concentración promedio final fue de $98,30 \mathrm{mg} / \mathrm{dl}$ después del ejercicio de alta intensidad. Fueron encontradas diferencias significativas al comparar la concentración inicial con la concentración final de lactato. Conclusiones: La concentración de lactato aumenta con la realización de actividad física, es variable de un individuo para otro, y puede ser usada como biomarcador de intensidad de la actividad física en el área de los deportes. Nivel de evidencia ll; Estudios pronósticos - Investigación del efecto de característica de un paciente sobre el resultado de la enfermedad

Descriptores: L-lactato deshidrogenasa; Metabolismo basal; Metabolismo de los hidratos de carbono; Medicina deportiva; Fuerza muscular; Fatiga muscular.

\section{INTRODUCTION}

Time ago, it was thought that lactate was a waste product, produced during lactic fermentation; nowadays, this concept has been completely replaced, considering lactate as an intermediate product that provides multiple benefits, among them, the facilitation of long-term memory consolidation ${ }^{1,2}$. This metabolite is constantly produced in the body under resting conditions and reaches the maximum or subsequent thresholds of a training day, thus, the concentration of lactate in the blood is one of the factors that determine and trigger its re-synthesis process and removal as a fundamental part of metabolism.

Lactate threshold $(\mathrm{LT})$ is defined as the point at which blood lactate begins to accumulate above resting levels during an exercise of increasing intensity ${ }^{3}$; associated with it, this increase is a determining factor in the performance of an athlete, as the intensity and speed of work execution is increased above $1.4 \mathrm{~m} / \mathrm{s}$, blood levels increase rapidly until reaching the threshold. The constant training in these threshold levels allows to acquire physiological adaptations that lead to the recruitment of new muscle fibers in order to fully comply the physical exercise that has been planned ${ }^{3,4}$.

On the other hand, the development of a planned, structured and repeated training ${ }^{5}$ produces a constant muscular contraction that generates an energy expenditure above the resting metabolic level ${ }^{4}$. This energy expenditure generates variation in the concentration of blood biomarkers, depending on the intensity, duration and frequency which the training is performed with, this integrated response to exercise is what allows an adaptation of the different systems that are activated during a sustained period, and at an appropriate intensity and frequency for the proper maintenance of organic functions, each person who practices sports requires an appropriate dosage, so that the exercise is carried out at intensities for generating positive changes.

During sports training, measuring the levels of biomarkers of physical effort, including lactate, can determine the dose of workload or the appropriate intensity for each individual to avoid injuries and overtraining, hence the objective of this study was to assess blood lactate concentrations in a group of Valle League weightlifting athletes as a tool to determine the effects of training and its direct relationship with performance during the competition.

\section{MATERIALS AND METHODS}

\section{Type of study}

A cross-sectional descriptive observational study in which blood lactate concentrations were evaluated in a group of Valle League weightlifting athletes as a tool to determine the effects of training and its direct relationship with performance during the competition.

\section{Population}

The study was conducted with 32 weightlifting athletes assigned to the Valle League weightlifting, with an average age of 20 years and a range between 18 and 25 years. The participants were selected for convenience and as an inclusion criterion it was established that they had not had muscle or bone injuries at the time of participating in this study, having a rest period of four (4) days prior to the first sampling at rest and finally that they were attached to the Valle League weightlifting.

Participants accepted to participate in this study, by reading and signing an informed consent explaining the objectives, the method of sampling and the risks of the investigation.

The Institutional Committee of Human Ethics of the National School of Sports University Institution (IUEND), governed by resolution 008430 of October 4, 1993 of the Ministry of Health of Colombia, which establishes the scientific, technical and administrative standards for the health research, approved the completion of this project, leaving it established in the Approval Act No. 4.1.01.03.17 October 3rd 2017.

\section{Training protocol}

The training was carried out in the Valle League weightlifting, this scenario has enough and necessary implements to fully develop the training protocol established by the coach.

A high-intensity training section was performed, the objective was the development of the technique and it was done through four sports gestures, performed at $80 \%$ of the maximum repetition (RM) of each athlete; 5 sets and 15 repetitions were performed for each sports gesture, with a period of 40 seconds of rest between each exercise.

The first sporting gesture was the POWER CLEAN, a power exercise which consists of a fast lifting of the bar from the floor to the front of the shoulders, with a squat position. The second sporting gesture was the POWER SNATCH, consisting of the bar lifting from the floor to the hips, taking impulse for carrying the bar quickly above the head and finishing the position with straight back, with extended arms without flexing elbows, aligning the bar with the body position. The third one was the SNATCH, this power exercise, which consists in the rapid execution of the sports gesture that leads to the lifting of the bar above the head in a single movement, taking momentum with the hip through a quick squat and ending in straight back position, arms extended without flexing the elbows, aligning the bar with the body.

Finally, the SQUATS, consists of performing squats while holding the bar above the head with the arms extended, this exercise should be performed with the back straight and with the feet shoulder-width apart.

\section{Sampling}

The initial sample was taken thirty (30) minutes after the athlete arrived at the training center and the final sample was taken at the 
end of the high intensity training section, corresponding to the one implemented by the coach.

The initial and final sampling was carried out in triplicate in order to obtain an appropriate measurement, said sampling was performed by specialized health personnel and certified for that purpose, using the same sample collection methodology before and after performed physical activity.

The biological material was collected by punizing the earlobe through a puncture with a sterile lancet (Accu-Chek ${ }^{\circledR}$, Softclix Pro, Germany), letting the blood flow without pressing in order to avoid hemolysis, then the blood sample was placed on a commercial lactometer band (Lactate Scout Reactive Strips from the Biolaster supplier), finally the strap with the sample was introduced into the analyzer or lactate meter (Biolaster supplier's Lactate Scout) which performed the sample reading and quantified the athlete's blood lactate level. This sampling was carried out following the norms of asepsis and antisepsis, in addition to following all the international biosafety protocols, and complying with the norms for scientific research with human beings in force at national and international level.

\section{Statistical analysis}

The results will be analyzed using SAS software version 9.3 for Linux with the GLM procedure. Using the software, a descriptive analysis was performed, obtaining the measures of central tendency and an analysis of variances was performed.

\section{RESULTS}

Blood lactate levels for an athlete may vary according to the intensity which the exercises are performed, (Table 1) shows the results of the measurement of blood lactate concentrations in 32 athletes, students (14 women and 18 men) attached to the Valle League weightlifting.

According to the results of the levels of the lactate measurements between men and women, it can be observed that the measurements of the resting lactate concentration or initial state for women have an average of $23.06 \mathrm{mg} / \mathrm{dl}$, with a value $15.31 \mathrm{minimum} \mathrm{mg} / \mathrm{dl}$ and a maximum value of $29.13 \mathrm{mg} / \mathrm{dl}$, and the measurements after the high-intensity exercise section or final state an average of $100.52 \mathrm{mg} / \mathrm{dl}$ is observed, between a minimum value of $26.30 \mathrm{mg} / \mathrm{dl}$ and a maximum value of $138.72 \mathrm{mg} / \mathrm{dl}$.

For men, the average concentration value in the initial state (rest) was $21.99 \mathrm{mg} / \mathrm{dl}$ with a minimum value of $16.21 \mathrm{mg} / \mathrm{dl}$ and a maximum value of $28.9 \mathrm{mg} / \mathrm{dl}$, while the amounts of Post-practice lactate (final state) it was obtained an average value of $96.58 \mathrm{mg} / \mathrm{dl}$, between a minimum value of $27.60 \mathrm{mg} / \mathrm{dl}$ and a maximum of $145.93 \mathrm{mg} / \mathrm{dl}$ (Table 2). In Figure 1, the average and standard deviation of measurements of lactate quantities between women and men can be observed.

Comparing the variations between the lactate concentrations taking as a reference the gender and without taking into account the initial or final state of the lactate concentration, there were no statistically significant differences between the male and female participants with a $p=0.7038$. (Table 3 )

Observing the variations between the initial state of the lactate concentration and its final state measurements and regardless of gender, in the results of the measurement of the lactate concentration statistically significant changes were presented with $p=0.0001$ after of intense physical activity. (Table 3)

In Figure 2, it can be observed that the lactate concentration behavior in men and women on average does not present a big difference between the states, although it can be observed that between the values of the final state of the concentration there is variation internally between the groups of men and women.
Table 1. Concentration of lactate levels in the studied population.

\begin{tabular}{|c|c|c|c|}
\hline Athlete (code) & Gender & $\begin{array}{c}\text { [initial Lactate] } \\
\text { (mg/dl) }\end{array}$ & $\begin{array}{c}\text { [final Lactate] } \\
\text { (mg/dl) }\end{array}$ \\
\hline 1 & Male & 17.9 & 34.0 \\
\hline 2 & Female & 20.5 & 90.5 \\
\hline 3 & Female & 21.6 & 26.3 \\
\hline 4 & Male & 20.6 & 27.6 \\
\hline 5 & Masculino & 22.6 & 45.1 \\
\hline 6 & Female & 24.5 & 86.0 \\
\hline 7 & Male & 16.21 & 128.81 \\
\hline 8 & Female & 18.92 & 122.51 \\
\hline 9 & $F$ female & 25.22 & 29.3 \\
\hline 10 & Male & 17.12 & 75.67 \\
\hline 11 & Male & 28.9 & 108.5 \\
\hline 12 & Male & 26.12 & 110.8 \\
\hline 13 & Female & 29.3 & 118.91 \\
\hline 14 & Male & 27.2 & 56.75 \\
\hline 15 & Male & 18.92 & 88.98 \\
\hline 16 & Female & 19.82 & 101.8 \\
\hline 17 & Male & 24.5 & 90.2 \\
\hline 18 & Female & 25.2 & 137.1 \\
\hline 19 & Female & 29.73 & 111.7 \\
\hline 20 & Male & 24.34 & 125.9 \\
\hline 21 & Male & 18.02 & 120.71 \\
\hline 22 & Male & 22.67 & 121.54 \\
\hline 23 & Female & 25.22 & 86.03 \\
\hline 24 & Female & 24.32 & 103.59 \\
\hline 25 & Male & 20.72 & 102.69 \\
\hline 26 & Female & 15.31 & 136.2 \\
\hline 27 & Male & 22.52 & 145.03 \\
\hline 28 & Male & 27.92 & 145.93 \\
\hline 29 & Male & 23.42 & 135.12 \\
\hline 30 & Female & 17.12 & 138.72 \\
\hline 31 & Male & 16.21 & 75.13 \\
\hline 32 & Female & 26.14 & 118.63 \\
\hline
\end{tabular}

Table 2. Lactate concentration description.

\begin{tabular}{c|c|c|c|c|c|c}
\hline Gender & State & $\mathbf{n}$ & media & $\begin{array}{c}\text { Standard } \\
\text { deviation }\end{array}$ & $\begin{array}{c}\text { Minimun value } \\
{[\mathbf{m g} / \mathbf{d l}]}\end{array}$ & $\begin{array}{c}\text { Maximun value } \\
{[\mathbf{m g} / \mathbf{d l}]}\end{array}$ \\
\hline \multirow{2}{*}{ Female } & Final & 14 & 100.52 & 35.58 & 26.30 & 138.72 \\
\cline { 2 - 7 } & Initial & 14 & 23.06 & 4.32 & 15.31 & 29.73 \\
\hline \multirow{2}{*}{ Male } & Final & 18 & 96.58 & 37.31 & 27.60 & 145.93 \\
\cline { 2 - 7 } & Initial & 18 & 21.99 & 4.04 & 16.21 & 28.90 \\
\hline
\end{tabular}

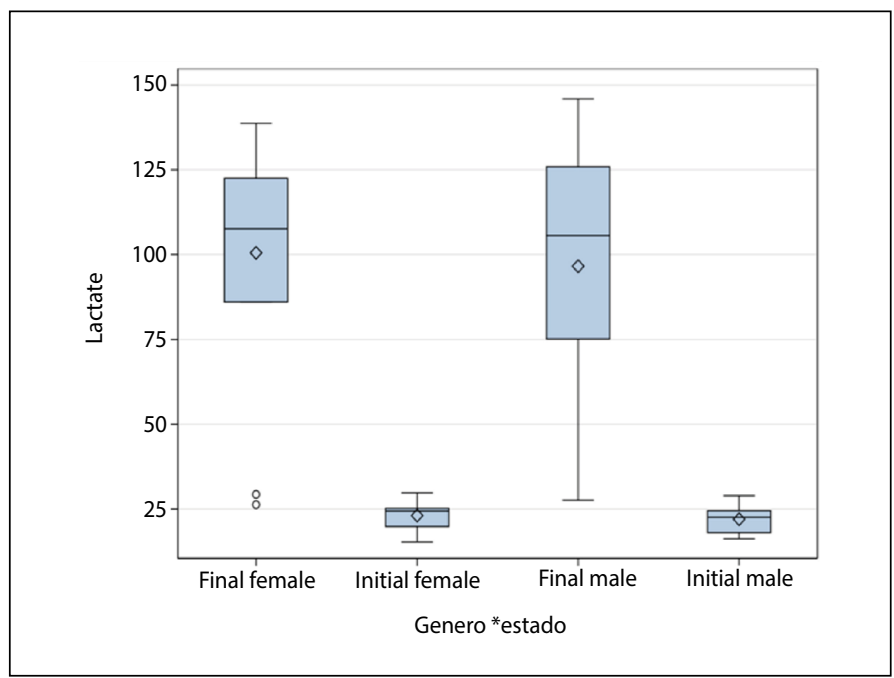

Figure 1. Standard deviation and media of lactate measures. 
Table 3. Variance of lactate concentration.

\begin{tabular}{c|c|c|c|c}
\hline Origen & Anova - Type III SS & Middle square & F - Value & P \\
\hline Gender & 98.83164 & 98.83164 & 0.15 & 0.7038 \\
\hline State & 91024.25750 & 91024.25750 & 134.39 & $<.0001$ \\
\hline Gender*state & 32.41486 & 32.41486 & 0.05 & 0.8276 \\
\hline
\end{tabular}

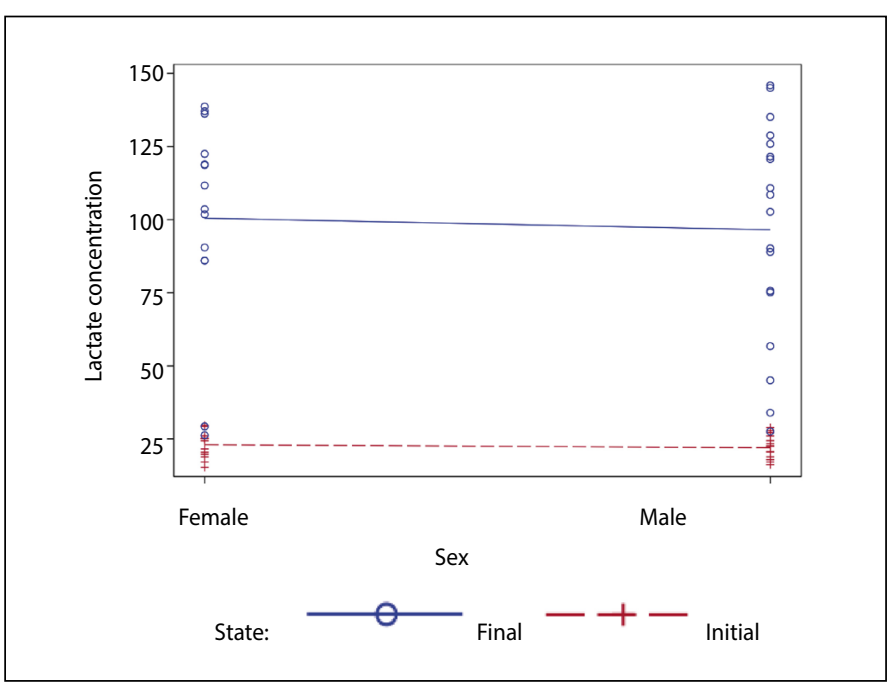

Figure 2. Interaction of state lactate concentration between the gender.

\section{DISCUSION}

The research objective was to evaluate blood lactate concentrations in a group of university athletes at rest and after of high intensity training, as a tool to determine the effects of training and its direct relationship with Performance during the competition.

When people or athletes undergo a set of high intensity exercises, their metabolism faces a series of changes that generate muscle fatigue, which is related to the production of lactic acid, a strong acid, which quickly transforms into a molecule of negatively charged lactate and a hydrogen cation 5 .

In the results it can be observed that blood lactate levels among the participants are variable, although no statistically significant differences were found between men and women, the body's muscles always produce lactate, but their concentration is increasing in parallel with the intensity of exercise, the metabolism of each individual and the genetic characteristics as well6-8.

Also in the results it is observed, the variation between the initial and final lactate levels of the participants, this may be caused by some of the participating individuals having more sports life, this implies a longer time in the practice of these exercises, so they have a higher production of lactate, and also a greater assimilation and removal; our results were similar to those obtained in other investigations where lactate levels were evaluated to determine the intensity of the effort in competition

and concluded that blood lactate concentration is sensitive to changes in exercise intensity and duration ${ }^{9-11}$. It has also been reported that the measurement of lactate levels in swimming athletes and in other disciplines with high performance athletes, the measurement of lactate levels are determinants to control the specific performance of the athletes and are the basis for the evaluation of the training in each of the working rhythms, since it is the best metabolic indicator of the effort that allows to dose the training load ${ }^{12,13}$.

Lactate levels can increase exponentially until reaching what is called the lactate threshold, which occurs at a blood concentration of $4.0 \mathrm{mmol} / \mathrm{L}^{8}$, fatigue appears quickly if it is above the lactate threshold limit; however, performing much of the training at the limit of the lactate threshold or above may result in overtraining, which is why the measurement of blood lactate levels is used to determine the correct intensity of exercise and the time required for recovery ${ }^{14}$. In most athletes and people who practice sports, there is a belief that lactate is a product of metabolic waste and that causes muscle fatigue; however, it has been reported in other research that lactate is not an enemy of sports performance, that it is not a waste product but a source of carbohydrates that competes with glucose, and the glucose found in the blood is reserved for the use of other tissues for later use in Long-term and more intense tests ${ }^{15}$, so it is suggested that most of the lactate taken by the muscles is transformed by the oxidative route ${ }^{16}$; in that way, lactate is an important gluconeogenic precursor, both at low and moderate intensities, and is possibly, the most important substrate of gluconeogenesis ${ }^{17-19}$. Other studies have shown that, far from causing muscle fatigue in exercise, lactate production prevents fatigue, counteracting the depolarization effects produced by the release of potassium ions into the extracellular space, which allows ions of calcium released from the endoplasmic reticulum and finally the contraction of muscle fiber is triggered ${ }^{20}$.

Lactate is an intermediate in the metabolism of glucose in skeletal and cardiac muscle, erythrocytes and other tissues, its accumulation depends on the energy demand of the muscle, the contribution and the oxidative capacity of this tissue, therefore, its removal o accumulation plays an important role in general physical activity, given that the higher the concentration of lactate or its production rate, the greater the intensity of the work performed. Taking into account that the stages of preparing athletes for the competitions involve weekly training and recovery cycles, understanding the behavior of blood biomarkers such as lactate would help better training planning to achieve a physiological adaptation of improvement without reaching the envelope.

Lactate as a biomarker of physics in weightlifting athletes, is also a fundamental tool in determining the fulfillment or not of the objectives of the training, which is carried out by monitoring the levels of lactate in the blood; for this particular study the objective of training was the development of the technique. Different studies on the glial cells of the hippocampus, have led to evidence that the transport of lactate astrocycito-neuron, develops a critical role in the formation of long-term memory ${ }^{21-23}$. This feature is associated with variations in lactate levels and the development of long-term neuroplasticity and memory formation, this will allow the athlete to optimize their training processes, increasing cognitive adaptations in athletes who allow an adequate appropriation of the technique at the time of the execution of the sports gesture, thus contributing to increase efficiency and performance in competition while reducing the risk of injury.

Based on our results, it is possible to conclude that the determination of blood lactate levels is a valuable tool that allows to determine the effects of training, in the organism of the athlete, since it allows to know the changes and metabolic adaptations that arise inside of said organism, all this in order to establish a direct relationship with sports performance during the different stages of the training macrocycle.

In addition, it allows the implementation of personalized training programs in order to maximize the innate characteristics of each athlete, in order to generate as many cognitive adaptations as possible that allow an adequate appropriation of the technique in the long term, increasing efficiency, performance and reducing the risk and appearance of injuries.

Finally, it is possible to conclude that the lactate concentration increases with the completion of the period of physical activity. It is variable in each individual and can be used as a measurable biological marker, with it, the change of a condition or process can be objectively monitored during a period of time determining the dosage of load or intensity of work. 


\section{ACKNOWLEDGMENT}

To the Valle League weightlifting head of Dr. Pedro Vicente Córdoba, its honorable coach Jaime Manjarres and to the Research Group on Sport and Human Performance of the University Institution National School of Sport.
The results of this study are presented clearly, honestly, and without fabrication, falsification, or inappropriate data manipulation, and statement that results of the present study do not constitute endorsement by ACSM.

All authors declare no potential conflict of interest related to this article

AUTHORS' CONTRIBUTIONS: Each author made significant individual contributions to this manuscript. DCZR, YMP, AJMM, ICRP:Writing, data analysis, review of the article, intellectual concept of the article and approval of the final version to be published.

\section{REFERENCES}

1. Brooks, G.A. Cell-cell and intracellular lactate shuttles. J Physiol. 2009;587(Pt 23):5591-600.

2. Schumacher YO, Vogt S, Roecker K, Schmid A, Coyle EF. Scientific considerations for physiological evaluations of elite athletes. J Appl Physiol. (1985). 2005;99(4):1630-1.

3. Nightingale AM, Leong CL, Burnish RA, Hassan SUI, Zhang Y, Cloughet GF, et al. Monitoring biomolecule concentrations in tissue using a wearable droplet microfluidic-based sensor. Nat Commun. 2019;10(1):2741.

4. Robson EK, Kamper SJ, Davidson S, Viana da Silva P, Williams A, Hodder RK, et al. Healthy Lifestyle Program (HeLP) for low back pain: protocol for a randomised controlled trial. BMJ Open. 2019;9(9):e029290.

5. Morell MM, Gonzáles C, Llop F. Present and future of lactic acid. Arch Med Deporte. 2007:24(120):270-284.

6. Brooks GA. Intra and extra cellular lactate shuttles. Med Sci Sports Exerc. 2000;32(4):790-9.

7. StanleyWC, Gertz EW, Wisneski JA, Neese RA, Morris DL, Brooks GA. Lactate extraction during net lactate release in legs of humans during exercise. J Appl Physiol (1985). 1986;60(4):1116-20.

8. Van Hall G, Calbet JAL, Sondergaard H, Saltin B. Skeletal muscle carbohydrate and lactate metabolism after 9 wk of acclimatization to 5,260 m. Am J Physiol Endocrinol Metab. 2002;283(6):E1203-13.

9. Souglis A, Bogdanis GC, Giannopoulou I, Papadopoulos Ch, Apostolidis N. Comparison of inflammatory responses and muscle damage indices following a soccer, basketball, volleyball and handball game at an elite competitive level. Res Sports Med. 2015;23(1):59-72.

10. Van Schuylenbergh R, Vanden Eynde B, Hespel P. Correlations between lactate and ventilatory thresholds and the maximal lactate steady state in elite cyclists. Int J Sports Med. 2004;25(6):403-8.

11. Beneke R, Leithäuser RM, Ochentel O. Blood lactate diagnostics in exercise testing and training. Int J Sports Physiol Perform. 2011;6(1):8-24

12. Vasile L. Endurance Training in Performance Swimming. Procedia Soc Behav Sci. 2014:117:232 - 237.
13. Quintero-Burgos Rl, Manrique-Abril FG. El lactato sanguíneo y su correlación con biomarcadores salivales, como indicadores de la intensidad del ejercicio. Rev salud hist sanid on-line. 2011; 6(1):3-11.

14. Włodarczyk M, Kusy K, Słomińska E, Krasiński Z, Zieliński J. Change in Lactate, Ammonia, and Hypoxanthine Concentrations in a 1-Year Training Cycle in Highly Trained Athletes: Applying Biomarkers as Tools to Assess Training Status. J Strength Cond Res. 2020;34(2):355-364.

15. Miller BF, Fattor JA, Jacobs KA, Horning MA, Suh SH, Navazio F, et al. Metabolic and cardiorespiratory responses to "the lactate clamp". Am J Physiol Endocrinol Metab. 2002;283(5):E889-98.

16. Kelley KM, Hamann JJ, Navarre C, Gladden LB. Lactate metabolism in resting and contracting canine skeletal muscle with elevated lactate concentration. J Appl Physiol (1985). 2002;93(3):865-72.

17. McMorries RM, Joubert DP, Jones EJ, Faries MD. A Validation Study of a Noninvasive Lactate Threshold Device. Int J Exerc Sci. 2019;12(2):221-232.

18. Miller BF, Fattor JA, Jacobs KA, Horning MA, Navazio F, Lindinger MI, et al. Lactate and glucose interaction during rest and exercise in men: effect of exogenous lactate infusion. J Physiol. 2002;544(3):963-75.

19. Roef MJ, de Meer K, Kalhan SC, Straver H, Berger R, Reijngoud DJ. Gluconeogenesis in humans with induced hyperlactatemia during low-intensity exercise. Am J Physiol Endocrinol Metab. 2003;284(6):E1162-71.

20. Overgaard K, Højfeldt GW, Nielsen OB. Effects of acidification and increased extracellular potassium on dynamic muscle contractions in isolated rat muscles. J Physiol. 2010;588(Pt 24):5065-76.

21. Descalzi G, Gao V, Steinman MQ, Suzuki A, Alberini CM. Lactate from astrocytes fuels learning-induced mRNA translation in excitatory and inhibitory neurons. Commun Biol. 2019;2:247.

22. Suzuki A, Stern SA, Bozdagi O, Huntley GW, Walker RH, Magistretti PJ, et al. Astrocyte-neuron lactate transport is required for long-term memory formation. Cell. 2011;144(5):810-23.

23. Newman $L A$, Korol DL, Gold PE. Lactate produced by glycogenolysis in astrocytes regulates memory processing. PLoS One. 2011;6(12):e28427. 